\title{
Slotting Allowances and the Retail Sale of Alcohol Beverages
}

\author{
Gregory T. Gundlach and Paul N. Bloom
}

\begin{abstract}
Considerable controversy and debate surrounds the practice of slotting allowances, or fees, paid by manufacturers for obtaining the patronage of retailers. To date, regulators have yet to agree on public policy toward these practices; at least one federal antitrust agency suggests that slotting fees may be competitive, another has conducted investigations into these practices, and still another suggests banning them altogether. In this article, the authors examine the recent decision by the Bureau of Alcohol, Tobacco, and Firearms (BATF) to prohibit slotting allowances in the retail sale of alcohol beverages. Focusing on the regulatory environment, industry structure, marketing practices, and consumer consumption behavior in the alcohol beverage industry, the authors analyze the BATF's decision and attempt to reconcile disparate public policy treatment of these practices. Implications for understanding slotting allowances and recommendations for further public policy development and research then are explored.
\end{abstract}

$\mathbf{S}$ lotting allowances, or fees, are becoming increasingly controversial (Lariviere and Padmanabhan 1997; Shaffer 1991). These payments to retailers for stocking and displaying new products, or for other support services, have drawn criticism from manufacturers, small retailers, public policymakers, and scholars (Cannon and Bloom 1991). Complaints have centered around the potential for these fees to be applied discriminatorily (because they often are negotiated secretly), harmful to both small manufacturers and small retailers, and generally, a symptom of unfair abuse of retailer power. In contrast, those who defend these fees regard them as simply a risk-transfer mechanism and their use as a basis for signaling the quality of new products so that retailers can be more efficient in selecting and promoting merchandise (Kelly 1991).

Most recently, slotting allowances have come under the scrutiny of the Treasury Department's Bureau of Alcohol, Tobacco, and Firearms (BATF), in its regulation of the retail sale of alcohol beverages. Historically, slotting fees have been discouraged by the BATF on the basis that such practices might be competitively exclusionary and threaten retailer independence, which are important considerations under the Federal Alcohol Administration (FAA) Act (1935). However, prompted by previous court decisions regarding the BATF's interpretation of how certain promotional approaches should be treated under the Act, the BATF adopted regulations in 1995 that ban slotting allowance practices in the retail sale of alcohol beverages $(60 \mathrm{Federal}$ Register 20402).

Gregory T. GundLaCh is an associate professor, Department of Marketing, University of Notre Dame. PAUL N. Bloom is Professor of Marketing, Kenan-Flagler Business School, University of North Carolina, Chapel Hill. The authors extend their appreciation to members of their respective departments, the $J P P \& M$ reviewers, and the editors for their helpful comments. Easwar Iyer and George Milne served as editors for this article.
The BATF's prohibition represents a significant departure from standing public policy toward slotting allowances as administered by the other federal agencies responsible for overseeing competitive practices. Although it reportedly has investigated slotting allowances as far back as 1990 and suggested their discriminatory application may be unlawful (Federal Trade Commission Guides 1990), to date, the Federal Trade Commission (FTC) has not challenged such practices as anticompetitive. Activity in the Justice Department (JD), until recently, has been similarly skeptical of the potential anticompetitive nature of these practices (McCabe 1996). In a recent investigation, however, the JD reportedly examined the prospect that the payment of slotting fees by large competitors might have disadvantaged smaller rivals in the salty-snack industry (Greenwald 1996).

In this article, we examine slotting allowance practices in the retail sale of alcohol beverages. As background, we first overview the nature, controversy, and public policy surrounding slotting allowances. We then focus on public policy treatment of these practices in the retail sale of alcohol beverages and their recent prohibition by the BATF. Comparatively examining the regulatory environment, industry structure, marketing practices, and consumer consumption behavior found in the alcohol beverage industry versus other grocery products, we analyze the BATF's decision. This analysis reveals key differences in the retail sale of alcohol beverages and provides a basis for more clearly understanding the BATF's contrary policy toward these practices. From this analysis, we then derive implications for understanding slotting practices in general and recommendations for the development of further public policy and academic research.

\section{Background}

Slotting allowances have been defined broadly as "fees paid by manufacturers to obtain retailer patronage" (Shaffer 1991, p. 120). As we illustrate in Table l, these can include 
Table 1. Slotting Allowance Practices

Label

Appointment fees

Presentation/listening fees

Survey fees

Stocking allowances

Slotting fees

Annual renewal/

maintenance fees

Failure fees

\section{Description}

Fees for making new product presentation appointment.

Fees for the privilege of making new product sales presentations.

Fees for responding to questionnaires aimed at gauging demand for a new product.

Fees for price cuts made on existing products to make room for a new product.

Fees or free cases of product, or both, to stock a new product.

Fees to keep a new product on store shelves or maintain slow-moving products or all products in general.

Fees for removal of products that do not meet expected sales goals. a range of fees for virtually every stage of a product's presence in retail stores. For example, beyond fees or other remuneration for stocking a product, fees for appointments (e.g., appointment and presentation fees), removing old products, or cutting prices on slow-moving products have been reported (Donahue 1989; Kiley 1989; Progressive Grocer 1991). Slotting fees are said to provide compensation for the basic overhead associated with products, personnel hours, computer time, and other costs of making arrangements for new items (Cannon and Bloom 1991; Partch, Duff, and Litwak 1990).

Mechanisms through which such fees most commonly are paid include cash payments; free goods; and introductory, sampling, off-invoice, or spoilage allowances (Progressive Grocer 1991). Usually, slotting fees are negotiated orally and in private; therefore, little public data are available as to their nature and effect. An industry report estimates the magnitude of these fees nationwide as averaging, across all categories on a per-store basis, approximately $\$ 42$ per stockkeeping unit (Progressive Grocer 1996). Aggregately, however, companies have reported paying between $\$ 300,000$ and $\$ 1.5$ million per new product and from one-third (Smith 1990) to almost one-half (Therrien 1989) their promotion budgets to cover these fees (cf. Sales and Marketing Management 1989). Nevertheless, it is not clear that all manufacturers are paying slotting fees (Freeman and Dagnoli 1988; Gibson 1988; but see Sales and Marketing Management 1989) on all products (Hammonds and Radtke 1990). Also, it is not clear how far slotting allowances have spread beyond the grocery industry, such as into the book, software, and pharmaceutical industries.

\section{Controversy and Debate}

Advocates of slotting allowances suggest they are justified because of the efficiencies they yield and the role such fees play in the overall distribution system. These supporters contend slotting fees provide a form of "insurance" (Antitrust and Trade Regulation Report 1994; Kiley 1990b), or "performance bond" (Kelly 1991), in the event new products do not sell and, therefore, compensate retailers for "failure risks" and "opportunity costs" associated with new products. In addition, advocates suggest these fees provide a valuable source of information about the likely success of a new product. Slotting fees, they argue, can serve as a "market signal" that enables manufacturers to distinguish their product innovations efficiently and credibly communicate their beliefs and intentions regarding such products (Kelly 1991).
Those who oppose slotting allowances argue that retailer justifications for these practices do not always exist, or where they do, it is not clear whether the manufacturer or retail seller is in the best position or should be responsible for bearing the costs (Dagnoli and Freeman 1988). Moreover, when manufacturers and product suppliers agree to pay slotting fees, the fees imposed reportedly bear little relation or are intractable to the true costs retailers claim (Gibson 1988). Manufacturers and suppliers contend that retailers, realizing the profit potential of these fees and their newfound market power, often engage in these practices simply to increase profits rather than to offset real costs, thereby creating widespread discrimination and abuse (Johnson 1988). In addition, such practices allegedly are employed competitively by aggressive rivals as a basis for foreclosing smaller competitors through bidding up these fees (cf. Greenwald 1996). Concern for innovation (Gorman 1988) and the welfare of small manufacturers, wholesalers, retailers (Kiley 1990a), and consumers (Therrien 1989) also has been expressed (cf. Charlier 1994; Jones 1991; Radtke 1990).

\section{Public Policy}

Public policy activity by federal antitrust authorities has yet to yield a conclusive position on the competitive implications of slotting allowance practices. ${ }^{1}$ In the early 1990 s, the FTC was reported to be investigating such practices (Freeman and Dagnoli 1988; Gibson 1988; but see Progressive

\footnotetext{
ISimilarly, the courts have not developed a cogent posture toward slotting allowance practices. Court cases and formal complaints by private parties specifically involving slotting allowance practices have not been widespread. A legal database (LEXIS, August 24, 1996) search of both federal and state cases containing the terms "slotting fee" and "slotting allowance" and their derivatives resulted in identification of only eight cases. Only seven of these cases substantively addressed slotting allowance practices. The issues litigated in these cases range from disagreements regarding promises to pay such fees (Dunkirk Ice Cream Co. v. Mid-Atlantic Ice Cream Co. 1996; E.J. Brock Corp. v. Filbert Int'l. Inc. 1991; Scotts of Wisconsin v. R.P.S. Distributors 1993) to the discriminatory use of stotting fees (Hygrade Milk \& Cream Co. v. Tropicana Produce 1996; Land O'Lakes. Inc. v. Fredjo's Enterprises 1992) to the relevance of slotting fees in analyzing the competitive environment attendant to a merger case (Penmsylvania v. Russell Stover Candies Inc. 1993) to a franchise dispute (Beloit Beverage Co. v. Winterbrook Corp. 1995). In each case, slotting fees as a marketing practice were not found to be violative of the antitrust laws. The lack of widely accepted descriptors and the evolving nature of slotting allowance practices may underlie the perceived contrast between the limited number of cases and formal complaints and the widely reported debate surrounding slotting fees.
} 
Grocer 1990), but a disclosure of findings by the agency has not been made public to date, though the agency has indicated that the discriminatory application of slotting fees may be unlawful (Federal Trade Commission Guides 1990). ${ }^{2}$ Indirectly, published statements by an FTC commissioner and one staff member (Kelly 1991) suggest that such practices may enhance efficiency and, therefore, be regarded as competitively justified, if not desirable, by the FTC (cf. Freeman and Fahey 1990). As was stated by Commissioner Deborah K. Owen (Antitrust and Trade Regulation Report 1994, p. 703; 60 Federal Register 20409), slotting fees provide

a form of insurance for the retailer ... [that] reduce, and perhaps eliminate [its] risk-or at least transfer some of it to the producer-by charging a fee that essentially provides indemnification from the loss of profits that would arise if the new product fails to sell well.

Somewhat in contrast and more recently, an investigation of the salty-snack food industry by the JD reportedly focuses on slotting allowance practices as a mechanism of competitive foreclosure (Greenwald 1996). Investigators are attempting to assess whether firms are purchasing more shelf space than they need through slotting fees and other practices in an effort to foreclose less resourceful rivals anticompetitively. Antitrust observers point out, however, that the JD investigation stands in contrast to extant policy, given that the federal agency has not challenged shelf space practices in more than a decade (Greenwald 1996).

\section{Slotting Allowance Practices and the Retail Sale of Alcohol Beverages}

Although slotting allowance practices may be observed with increasing frequency in the retail sale of grocery products and other retail categories (Shaffer 1991), their practice in the retail sale of alcohol beverages generally has not been permitted under the FAA Act (1935), as administered by the BATF. The historical context of this Act as it relates to alcohol consumption provides the basis of this prohibition. Recently, prompted by a Court of Appeals decision and as a result of an agency review and petition by members of the

\footnotetext{
2The FTC's revised 'Guides for Advertising Allowances and Other Merchandising Payments and Services" provides that "[T|he discriminatory purchase of display or shelf space, whether directly or by means of socalled allowances, may violate the Act and may be considered an unfair method of competition in violation of section 5 of the Federal Trade Commission $\mathrm{Acl}^{\prime}$ (n. 40). The explanation that accompanies this footnote explains the FTC's view (MacAvoy 1997). According to the FTC, a distinction is drawn between payments that are made "for admittance to a store" and those that are made on an ongoing basis "for preferential position with the store" ( $N$, 40). Payments of the first type "concern the original sale from seller to customer, and do not differ in substance from a price cut, the paradigm application of section 2(a)" (N. 40) of the Robinson-Patman Act. In contrast, purchases that involve ongoing payments for preferential shelf or display position fall "more readily" within Section 2(d), because they have a nexus to the product's subsequent resale. Section 2(d) is a per se provision requiring only a demonstration of discrimination for a violation to be found. The explanation therefore suggests that discriminatory application of slotting allowances may be considered by the FTC a per se violation of Section 2(d) of the Robinson-Patman Act. See also Aalberts and Judd (1991)
}

industry, the BATF proposed to amend trade practice regulations under the FAA Act to prohibit slotting allowance fees and their practice in the retail sale of alcohol beverages. In this section, we review specific aspects of the FAA Act that relate to slotting allowances and then describe the BATF's regulatory proposal and adopted regulations. 3

\section{Federal Alcohol Administration Act}

The FAA Act provides for federal regulation of the alcohol beverage industry. The Act contains specific restrictions that are unique to this industry and reflects Congress's concern with a variety of trade practices and abuses that originated before, during, and immediately after Prohibition. These restrictions detail particular activities in the sale of alcohol beverages to a retailer by a producer (e.g., distiller, brewer, rectifier, blender), importer, wholesaler, or bottler as unfair competition or otherwise unlawful practices. In Table 2, we describe these practices and their characteristics. To result in a violation of the FAA Act, a necessary element for each of the restricted practices is the "exclusion, in whole or in part, of distilled spirits, wine, or malt beverages, sold or offered for sale by other persons" (27 USCA 205 [a-d]). Although "exclusion" is not defined under the Act or its regulations, historically the BATF has held that "exclusion in part" includes "causing retailers to purchase less of a competing brand than they otherwise would have bought" (59 Federal Register $21698-01$, p. 1). In a recent court ruling involving a New Jersey distilled spirits wholesaler, Fedway Associates, this interpretation was challenged successfully and required to be modified.

\section{Fedway Associates Inc. v. BATF (1992)}

In 1986, Fedway initiated a moderately successful, shortterm promotion to increase the sales of vodka and rum to retail establishments. Fedway offered retailers consumer electronic goods, including televisions and videocassette recorders, if they agreed to buy certain quantities of specified liquor. The promotional campaign lasted three months and successfully boosted Fedway's sales. In 1989, the BATF charged Fedway with a violation of the FAA Act, citing its promotional arrangement as exclusionary to rival wholesalers. The BATF endeavored to suspend Fedway's permits for the sale of alcohol beverages because of the promotion. Fedway appealed the initial decision against its practices to the U.S. Circuit Court of Appeals.

The Court of Appeals held that the promotional program did not result in the exclusion of rival wholesalers. Interpreting congressional intent in the promulgation of the FAA Act, the court observed that Congress had intended "exclusion" to mean something more than just a retailer purchasing less of a competing brand than it otherwise would have. Merely taking some action that influenced a retailer not to purchase a rival product, in the court's view, was not exclusion under the Act if the retailer's response was the result of a free economic choice. For a violation of the Act to occur,

\footnotetext{
3I is important to point out that our analysis does not focus on state regulations pertaining to the retail sale of alcohol beverages because of their varying requirements and our focus on federal law.
} 
Table 2. Federal Alcohol Administration Act: Unfair Competition and Unlawful Practices Relating to Slotting Allowancesa

It shall be unlawful for any person engaged in business as a distiller, brewer, rectifier, blender, or other producer, or as an importer or wholesaler, of distilled spirits, wine, or malt beverages, or as a bottler, or warehouseman and bottler, of distilled spirits, directly or indirectly or through an affiliate:

(a) Exclusive outlet. To require any retailer to purchase any such products to the exclusion of alcohol beverages sold by other persons in interstate or foreign commerce;

(b) "Tied house". To induce through any of the following means, any retailer, to purchase alcohol products to the exclusion of alcohol beverages sold by other persons: (1) by acquiring or holding any interest in any license with respect to the premises of the retailer; or (2) by acquiring any interest in real or personal property owned, occupied, or used by the retailer in the conduct of his business; or (3) by furnishing, giving, renting, lending, or selling to the retailer, any equipment, fixtures, signs, supplies, money, services, or other thing of value; or (4) by paying or crediting the retailer for any advertising, display, or distribution service; or (5) by guaranteeing any loan or the repayment of any financial obligation of the retailer; or (6) by extending to the retailer credit for a period in excess of the credit period usual and customary to the industry; or (7) by requiring the retailer to take and dispose of a certain quota of any of such products;

(c) Commercial bribery. To induce through any of the following means, any trade buyer, to purchase alcohol products to the exclusion of alcohol beverages sold by other persons: (1) by commercial bribery; or (2) by offering or giving any bonus, premium, or compensation to any officer, or employee, or representative of the trade buyer;

(d) Consignment sales. To sell to any trade buyer, or for any such trade buyer to purchase any alcohol beverage products on consignment or under conditional sale or with the privilege of return or on any basis otherwise than a bona fide sale.

aSummarized from 267 USCA 205(a-d).

according to the court, there must also be a tie or link between the supplier (e.g., wholesaler) and retailer that threatens the retailer's independence (e.g., freedom of choice) and results in the exclusion of a rival.

The overriding concern expressed by the court was the hindrance of legitimate competitive activities by the enforcement actions of the BATF. The court ruled that, in future enforcement activities, the BATF should take reasonable account of both (1) policy interests underlying the trade practice provisions of the FAA Act (i.e., that the alcohol industry requires special oversight and regulation) and (2) the value of procompetitive wholesale activities. This value derives from not only the traditional benefits of competition, in terms of lower prices and improved quality, but also a competitive alcohol market helping deter the formation of a corrupt black market. The court further held that, in arriving at a reasonable interpretation of "exclusion," the BATF must take care to distinguish rationally between those activities it decides are lawful and those that are not.

\section{Proposed Amendments to Regulations of the FAA Act}

In response to and, in part, prompted by the court, the BATF initiated a review and subsequent proposal $(59 \mathrm{Federal} \mathrm{Reg-}$ ister 21698) to amend and add to the regulations of exclusion by following a framework consistent with the interpretations in Fedway and a previous related case (Foremost Sales Promotions Inc. v. BATF 1988). The courts in both Fedway and Foremost held that "exclusion" as it is used in the FAA Act cannot occur in the absence of a relationship or arrangement between the industry member and the retailer that directly or indirectly threatens the retailer's independence. As proposed, the rulemaking procedures by the BATF were intended to (1) promulgate a framework for establishing "exclusion," (2) identify promotional practices that result in the control of retailers (i.e., threaten retailer independence), (3) identify practices that result in exclusion under the Act, and (4) identify practices for which there was no likelihood that exclusion would result and the BATF would not take action.

\section{Slotting Allowances}

The proposed regulations sought to include slotting fees as a promotional practice that threatened retailer independence and provided the basis for exclusion, as defined in the FAA Act. Under the proposed rules, slotting allowance arrangements were described as "purchasing or renting specific shelf space ... where such purchase reduces the availability of other shelf space" (59 Federal Register 21710; see also 60 Federal Register 20409).

In relation to slotting allowance practices, the BATF sought to identify such practices within the context of provisions that relate to the unfair trade practice known as "tied house" (27 USC 205[b]). (See Table 2.) This particular provision of the FAA Act prohibits inducements for retailers to purchase products from one supplier at the exclusion of others and extends from concerns of excessive influence and control on the part of suppliers during the days of Prohibition. Slotting practices were to fall within the tied house provisions in the capacity of a "wholesaler exerting control over a retailer through controlling the resetting of the products on a retailer's premise" (59 Federal Register 21698-01, 21699). Under the original Act, the BATF interpreted slotting fees as "things of value" given to retailers or as "paying or crediting the retailer for any advertising, display or distribution service" and investigated them as potential violations of the tied house provisions (cf. 60 Federal Register 20407). Under the BATF's proposed regulations, the payment of slotting fees was to be identified more particularly as exclusionary per se.

In addition, slotting allowance practices were to be identified as falling within the unfair trade practice provisions in the Act that pertain to "consignment sales" and the prohibition of "other than bona fide sales" (27 USC 205[d]). Such prohibited sales are defined to include "sales in connection with which the industry member bears the cost of display by 
purchasing or renting a trade buyer's shelf space to be occupied by such products" (59 Federal Register 21698-01, 21700 ). Under the amended regulations, slotting allowance practices were specified as a form of consignment sale and, therefore, prohibited by the FAA Act.

\section{Final Regulations}

In the spring of 1995, the Treasury Department amended the trade practice regulations under the FAA Act to prohibit slotting allowance practices in the retail sale of alcohol beverages as both a violation of the tied house provision and a consignment sale (60 Federal Register 20402-20428). After deliberations and considerable public input, 4 the BATF found that "slotting fees put retailer independence at risk" (60 Federal Register 20409) and therefore provide the basis for exclusionary outcomes. In addition, the BATF determined that the practical effect of these fees was a refund of the purchase price of a product that had not been sold, therefore making it an "other than bona fide sale" or consignment sale (60 Federal Register 20408-20409).

In explaining the rationale for its action, the BATF expressed concern regarding several possible negative outcomes of allowing slotting allowances, including the potential that

- More heavily slotted products could be overrepresented or "pushed" at the retail level, to the exclusion of other less supported products. 5

- Suppliers who are unwilling or unable to pay slotting allowances could be excluded from retail distribution because of the restricted number of lawful distribution alternatives available in the industry.

- Discrimination in the payment and receipt of slotting allowances could occur, especially toward small businesses (e.g., suppliers and retailers) because of their negotiated nature. 6

- Slotting fees, negotiated and paid on a continuing basis, could jeopardize retailer independence by establishing a quid pro quo relationship and result in exclusion by creating incentives to favor particular suppliers (e.g., those paying more).

- Slotting fees could alter the health, competitive environment, and performance of the alcohol beverage industry.

The BATF's decision included an expanded version of its original description of slotting fees. Under the adopted regulations, slotting allowance practices now are defined as

${ }^{4} \mathrm{An}$ important aspect of the BATF's decision-making process involved the solicitation of comments regarding the proposed rules under the Act. Comments were sought on whether slotting fees should be prohibited or allowed under the tied house and/or consignment sale regulations. A reported 1347 letters were received, with 1309 letters $(97 \%)$ in support of the BATF's stated position to prohibit slotting allowance practices $(60 \mathrm{Fed}$ eral Register 20407).

${ }^{5}$ The practice of slotting allowances also can be viewed as part of a larger phenomenon in the retail sector toward greater reliance on "push" marketing (i.e., the practice of providing incentives directly to the retail trade to create demand for a product) rather than "pull" marketing (i.e., marketing directly to end consumers through advertising and other strategies to create product demand) (Johnson 1988).

It has been asserted that slotting allowances are highly negotiable, with the retailer's ability to obtain and the manufacturer's willingness to pay such allowances being heavily dependent on the parties' relative market share and bargaining position. Such circumstances underlie the concerns for potential discrimination toward both manufacturers and retailers in the payment and receipt of slotting allowances. See also footnote 2. "the act by an industry member of purchasing or renting display, shelf, storage or warehouse space" (60 Federal Register 20424). The expanded definition extends the regulations to include more than just the purchase or renting of specific shelf space and reflects the conclusion that slotting allowance practices, as defined originally by the proposed regulations, were described too narrowly in content. ${ }^{7}$

\section{Analysis of the BATF Decision}

The prohibition of slotting allowance practices by the BATF in the context of the retail sale of alcohol beverages contrasts markedly with their acceptance in other markets. As we observed, with the exception of a warning against their discriminatory application (Federal Trade Commission Guides 1990) and the current investigation of shelf space practices in the salty-snack food industry by the JD, those federal agencies primarily responsible for overseeing competitive practices have not found publicly that slotting allowance practices offend antitrust laws.

Given the BATF's decision and the contrary perspectives toward slotting allowance practices held by the other federal agencies, a key question relates to the basis of these policy differences. In particular, what factors underlie and distinguish the prohibition of slotting allowances in the retail sale of alcohol beverages, relative to other circumstances in which such practices are allowed? Understanding these differences should help reconcile current public policy and facilitate our understanding of slotting fees. In this section, the decision of the BATF to prohibit slotting allowance practices is analyzed, with focus given to how alcohol beverage markets differ in terms of their regulatory environment, industry structure, marketing practices, and consumer consumption behavior.

\section{Regulatory Environment}

With the possible exception of tobacco and drugs, the regulation of alcohol beverages is unique in its policy goals, historical context, and enforcement approach.

\section{Policy Goals}

The regulatory goals accorded to the distribution of alcohol beverages reflects the policy judgment that infinite market penetration and availability of alcohol beverages is not a desired result. As was summarized cogently in a recent federal appellate court decision, "cheap and plentiful alcohol is not an unmitigated social good" (Fedway Associates Inc. v. $B A T F$ 1992, p. 1423). Relative to standard economic

\footnotetext{
${ }^{7}$ According to information obtained from the comments submitted, slotting allowance practices included a wide range of payments and arrangements, such as

- Setting up new products in a store or warehouse;

- Allocating a specified quantity of shelf or refrigerator space;

- Allocating a favorable shelf or display position;

- Featuring products in advertising during peak demand periods, such as holidays;

-Setting aside warehouse or back room space for storage; and

-Exclusively carrying a manufacturer's product(s) $(60$ Federal Register 20408).

These descriptions, some now incorporated in the revised regulations, characterize a more expansive arrangement than the simple purchase of shelf space, as was described by the original proposed regulations.
} 
notions in unregulated markets that encourage output expansion and the availability of products, a policy goal to regulate the distribution of alcohol beverages reflects a dramatically different policy perspective. Further understanding of the basis of this perspective can be obtained through examination of the legislative history of the FAA Act.

\section{Historical Context}

The FAA Act was enacted in 1935 and designed specifically to minimize the social and competitive problems of unregulated alcohol beverage distribution in the early days after the repeal of Prohibition. ${ }^{8}$ The Act represents congressional determination to combat what was perceived at the time to be an "unusually dangerous menace" (National Distributing Company Inc. v. BATF 1980, p. 1005) and one for which, because of "many factors not common to other industries," the antitrust laws were deemed "insufficient to accomplish the objective" (National Distributing Company Inc. v. BATF 1980, p. 1008; citing House Report No. 1542, 74th Congress, 1st Session 1935, pp. 5-6). In particular, Congress concluded that there was a close connection between economic abuses and "certain incidental social evils" connected with the distributional practices in the alcohol beverage industry (National Distributing Company Inc. v. BATF 1980, p. 1008; citing House Report No. 1542, 74th Congress, 1st Session 1935, p. 12). The Act sought to prohibit practices that resulted in these abuses and subsequent "social evils." According to the Senate Report (No. 1215, 74th Congress, 1st Session 1953, pp. 6-7) accompanying the Act,

The first class of these prohibited practices were those which tended to produce monopolistic control of retail outlets, such as arrangements for exclusive outlets, creation of tied houses, commercial bribery, and sales on consignment or with the privilege of return.... [C]ontrol by producers and wholesalers of retail outlets through the various devices such as those prohibited by the bill has been productive not only of monopoly but also of serious social and political evils which were in large measure responsible for bringing on prohibition (cited in National Distributing Company Inc. v. BATF 1980, p. 1008).

Producers or wholesalers were said to obtain control over independent retailers by providing financial and advertising assistance on the condition or agreement that the retailer would serve as an exclusive outlet, thereby providing the supplier with a competitive advantage.

The greater influence and control afforded producers and wholesalers from these tied house arrangements also was linked to a variety of social evils. Some considered these arrangements a source of political corruption. ${ }^{9}$ Other mem-

\footnotetext{
${ }^{8} \mathrm{As}$ was described in a key case (National Distributing Company Inc. $v$. $B A T F 1980$, p. 1005), this was a time when "the nation was infested with bootleggers and racketeers anxious to continue their trade and willing to thwart the tax and health laws."

9According to Joseph Choate, then Chairman of the FAA:

The larger distillers and brewers controlled scores, hundreds, and possibly thousands of such outlets. That inevitably threw them into politics, inevitably led them to seek control of state and municipal legislation, and brought about an unhealthy political condition (National Distributing Company Inc. v. BATF 1980, p. 1009; citing Federal Alcohol Control Act, Hearing on H.R. 8539 before the House Committee on Ways and Means, 74th Congress, 1 st session 1935, p. 10).
}

bers of Congress suggested that the influence and control wielded by suppliers was a cause for the proliferation of saloons and bars because of their financial assistance (National Distributing Company Inc. v. BATF 1980, p. 1009). Many believed such tied house arrangements increased the consumption of alcohol. ${ }^{10}$ Another expressed belief was that these arrangements would result in irresponsible ownership in retail outlets. ${ }^{11}$ As a result of these concerns, current federal law regarding the distribution and retail sale of alcohol beverages circumscribes a strict regulatory environment that is based on the underlying policy goal of regulating the output and controlling the availability of alcohol beverages.

\section{Enforcement Approach}

A particular dimension of this regulatory environment is the enforcement approach accorded market channel member relationships. Concern for the implications of undue influence and control by upstream suppliers and wholesalers has resulted in regulations and an enforcement approach that place great emphasis on retailer independence in the sale of alcohol beverages. As we detailed, practices such as slotting fees, which threaten this independence, are disfavored.

This treatment contrasts markedly with the current perspective of contemporary marketing channel theory, which suggests highly efficient channel systems involve interdependent channel members working closely together with one another (Stern, El-Ansary, and Coughlan 1996). This latter perspective underlies and informs the antitrust policy ascribed to by the JD and FTC. 12 The recognition that efficiency is not the only basis for policy toward alcohol beverages and that other factors, including the perceived social and political concerns extending from closer economic relations in the channel system, are also significant is critically important for understanding the contrary perspectives toward slotting allowance practices that are held by the BATF and these federal agencies.

Another dimension of the unique enforcement approach that emerges from the BATF's interest in retailer independence relates to the focus of enforcement efforts. Of particular interest to the BATF is the impact a specific practice

\footnotetext{
${ }^{10} \mathrm{As}$ reflected on by then-Congressman Lewis of Colorado:
}

One of the evils of the liquor traffic was that a retailer was required by the brewer or distiller to take a certain quota of beer or spirits of some private brand as a condition to being allowed to retail that brand. The temptation was often irresistible for the retailer to induce customers to buy drinks when they had already had quite enough (National Distributing Company Inc. v. BATF 1980, p. 1009; citing 79 Congressional Record 11797).

11 As stated by then-Senator Connally:

Is not it true in the old days a lot of the opposition to liquor and beer arose because of the fact that the brewers would put in sort of a sorry fellow who had no responsibility and no money to buy his equipment, and they would pay for his license and put him in his business, and he was usually the fellow who violated all the Sunday laws and every other kind of law? This is why the thing grew up. This evidently is based on that theory, that a man ought to have some personal responsibility to run a grog shop, not depending on the brewer financing him (National Distributing Company Inc. v. BATF 1980, p. 1009; citing 79 Congressional Record 11797).

12 Both these federal agencies and the majority of the courts now consider the sole goal of antitrust legislation to be efficiency and assess vertical channel practices on the basis of this goal (Sullivan 1977). 
has on an individual retailer versus the impact a practice might have on the entire retail market in a particular locale (60 Federal Register 20403-20404). Such an approach further contrasts with those approaches employed by the other antitrust agencies, which typically focus on the implications of a practice for the overall market.

\section{Industry Structure}

The distinctive structure of the alcohol beverage industry provides an additional basis for understanding the contrary treatment of slotting allowance practices by the BATF. Retail industry trends in the grocery industry are distinguishable from those for alcohol beverages. Moreover, given the nature of alcohol beverages and the variety of concerns underlying the FAA Act and other legislation; considerable restrictions attend the industry's distribution structure.

\section{Overall Structure}

A key factor often cited as contributing to the proliferation of slotting allowances in the grocery products industry is the occurrence of increased consolidation at the retail level (Shaffer 199l). Estimates indicate that supermarkets in general account for $73.4 \%$ of all grocery sales, with large supermarket chains accounting for more than $50 \%$ of this total (Aalberts and Judd 1991).13 This concentration, primarily the result of mergers, has provided retailers and particularly large chains with greater influence and control over suppliers in the payment of slotting fees.

Although these statistics also are applicable to some degree for the retail sale of alcohol beverages because many are sold through large retail chains, a mainstay of the alcohol beverage industry has been sales through retailers in the form of specialty liquor stores and on-premise bars, restaurants, and so forth. ${ }^{14}$ These retailers do not enjoy the influence and control the larger chains do in dealing with suppliers. Larger suppliers continue to dominate the industry and maintain considerable influence and control over these and other retailers. For example, for malt beverages, the top three brewers control in excess of $75 \%$ of the overall market. An important distinction, therefore, relates to the overall structure in the industry and the balance of influence and control held by its members. Although less influence and control undermines the ability of smaller retailers to require slotting fees, the presence of more powerful suppliers raises concerns for the independence of retailers by suppliers who pay these fees and the prospect that, if employed discrimi-

\footnotetext{
${ }^{13}$ As one reviewer pointed out, these national statistics actually may underestimate the concentration levels for smaller regional markets in which large supermarket chains hold dominant positions.

${ }^{14}$ Industry statistics report. for example, that in 1994, off-premise sales accounted for $53.9 \%$ of beer sales and $59.3 \%$ of wine sales (Adams/Jobson's Wine Handbook 1996a). In this same year, grocery retail sales (i.e. grocery stores and supermarkets, but not specialty liquor stores, delis. drugstores, mass merchandisers, and club stores) accounted for approximately $72.0 \%$ of off-premise beer sales and $33.0 \%$ of off-premise wine sales. Taken as a percentage of total sales, however, including off- and onpremise sales, grocery sales accounted for just $38.8 \%$ of retail beer sales and only $19.6 \%$ of retail wine sales (Adams/Jobson's Wine Handbook 1996b). Overall, beer sales accounted for $53.7 \%$ of total alcohol sales, and wine accounted for $12.5 \%$ and spirits $33.9 \%$ of these total sales (Adams/Jobson's Wine Handbook 1996b).
}

natorily, smaller suppliers might be foreclosed from access to such retailers.

\section{Distribution Structure}

Because of regulatory restrictions for the alcohol beverage industry at both the federal and state levels, licensed retail outlets provide the only practical and, in most cases, the exclusive means through which producers can sell their products to the public. Often, alcohol beverages may be sold only through a three-tier distribution structure that includes a limited number of licensed retail outlets (see generally the FAA Act and state laws relating to alcohol beverages). Several states even manage the distribution and sales of alcohol beverages themselves through "state stores."

The limited distribution structure found in the retail sale of alcohol beverages reflects the overall policy goal of regulating the widespread availability and dispersion of alcohol beverages. This derived structure presents unique challenges to manufacturers for introducing and marketing their products, especially smaller manufacturers that do not have the power to demand their way onto shelves. This circumstance, though not substantively unique to the alcohol beverage industry, presents a greater challenge, in degree, than is found in less regulated markets. A primary concern is that competition involving slotting fees in these channels could limit further the already restricted number of channels available to suppliers. The lack of widespread, alternate channels for introducing products would be particularly challenging for smaller firms, because of the constraints they face in paying such fees.

\section{Marketing Practices}

Another dimension on which slotting allowance practices in the retail sale of alcohol beverages can be distinguished from other retail circumstances relates to the marketing practices found in the alcohol beverage industry. In the following sections, we examine distinctive aspects of how (1) new alcohol beverage products are introduced, (2) margins are employed by retailers, and (3) other more general marketing practices are used.

\section{New Products}

The practice of slotting allowances in the retail grocery industry has been associated most often with the increasing proliferation of new products and the costs and risks these products impose on retailers (Hammonds and Radtke 1990). ${ }^{15}$ In addition, many grocery product categories are in the mature stage of their product life cycle. At this stage, line or brand extensions are a logical strategy (Johnson 1988), resulting in fewer "true" new products being introduced (Friedman 1990; Sales and Marketing Management 1989). Moreover, though data are not available, some industry observers contend that many of the new products introduced are presented with little market research, testing, or long-term promotional or advertising support, which results in high failure rates (Sales and Marketing Management

15 New product introductions in the retail grocery industry have grown from approximately 2000 in 1975 to 4000 in 1981 to more than 10.000 in 1988 (Sales and Marketing Management 1989) to 12,000 in 1990 (Friedman 1990; Shapiro 1990). 
1989). A review of new product failure rates indicates that these rates are at high levels-estimated as high as $80 \%$ (Shapiro 1990) to 90\% (Donahue 1989).

The nature of new products and the process and support provided for their introduction in the alcohol beverage industry contrasts with that found in the grocery retail business and provides some basis for distinguishing slotting allowance practices in this context. In particular, though increasing, fewer new alcohol beverage products typically are introduced each year than are products in many other categories of the grocery industry, and they have lower failure rates. (Tenser [1992] recognizes only 87 major malt beverage introductions from 1982 to 1992 , with 78 still on the market in 1992.) In part, this is due to the longer development times required for new alcohol beverages (Bronfman 1993).

The research and testing conducted for new alcohol beverage introductions also differs from that for many grocery products. New products often are introduced initially through "on-premise consumption" retailers (e.g., restaurants, bars) prior to their widespread introduction in grocery retail establishments. This process differs from grocery products, which most often are introduced directly to the retail store, and reduces considerably the risk of new product failure at the grocery retail level-a key rationale for slotting allowance practices in the grocery products industry.

The marketing support provided to new alcohol beverage products also differs in many respects from that given to more typical retail grocery goods. Where lawful, alcohol beverage manufacturers perform many of the retail tasks employed to justify grocery slotting allowances, including stocking, rotating, maintenance, removal of products, instore promotion, and so forth. Many of the costs associated with new products and their introduction therefore are borne by the manufacturer rather than by the retailer. In summary, the risks and costs associated with introducing new alcohol beverage products do not seem to be as high for retailers, which therefore provides some challenge to this as a basis for justifying slotting fees.

\section{Retailing}

In the grocery industry, retailers argue that low margins (average $1.5 \%$ ) on many products undercut their ability to absorb the costs and risks of new product introductions profitably, which therefore requires these costs and risks to be passed back to manufacturers in the form of slotting fees (Donahue 1987). In contrast, retailers of alcohol beverages receive much greater margins. Margins average approximately $24 \%$ for alcohol beverage retailers, which makes it harder to justify the need for slotting fees to offset the costs and risks associated with new products (Charlier 1994).

\section{Other Factors}

Grocery retailers also justify their use of slotting allowance practices by observing that they now have better access to sales and profitability information, which enables them to assess new product performance better (Sales and Marketing Management 1989). Advances in information technology, including checkout scanning, direct product profit information programs, and computer-assisted shelf space planning, provide grocery retailers with greater and more accurate performance information that enables them to assess and assign slotting costs more precisely (Dagnoli and Freeman 1988; Stern 1993). Retailers also contend that slotting fees compensate them for giving up shelf space that could be used by higher-margin private-label products. Private-label brands have become a dominant force in the grocery products industry, accounting for a growing share of products on retailer's shelves. However, many smaller retailers of alcohol beverages have not adopted information technology to the extent of large grocery retailers, nor have private labels obtained high levels of penetration in the industry (Shapiro 1994). Hence, retailers of alcohol beverages have a weaker set of arguments for justifying slotting allowance practices than grocery retailers do.

\section{Consumer Consumption Behavior}

Another important difference associated with the retail sale of alcohol beverages relates to the nature of consumer consumption behavior. Although alcohol beverages most often are sold through standard-format retail stores, a particularly high percentage of retail alcohol sales involve on-premise consumption in restaurants, bars, and so forth. On-premise consumption involves an estimated $45 \%$ of all alcohol beverage retail sales (Bellamy 1994; Rogers and Keene-Osborn 1994). This form of consumption behavior differs from that found for the majority of retail grocery products and further distinguishes slotting allowance practices in the retail sale of alcohol beverages. 16

An often-cited complaint against slotting allowance practices is the relation of slotting fees to the actual costs of new products. Slotting fees are argued to bear little relation to new product costs, and wide discrepancies in fees are reported across retailers (Gibson 1988). It is commonly believed that these inaccuracies reflect, among other things, errors associated with identifying and tracking new product costs and the assignment of such costs in the form of slotting fees (notwithstanding the increasing use of information technology). The widespread consumer practice of onpremise consumption in the sale of alcohol beverages results in added difficulties for measuring new product costs not typically found for grocery products. Moreover, many bars, restaurants, and such do not possess the sophistication required to identify and track these costs accurately and assess slotting fees precisely. Therefore, the potential efficiencies that justify slotting fees in the grocery industry appear less likely to be realized in the retail sale of alcohol beverages.

\section{Implications}

Our comparative analysis of the regulatory environment, industry structure, marketing practices, and consumer consumption behavior in the retail sale of alcohol beverages versus other retail goods, particularly grocery products, reveals a variety of key differences. These differences provide insight into the BATF's contrary policy treatment of slotting allowance practices in the retail sale of alcohol beverages. Understanding these differences helps reconcile cur-

16It is important to point out that the BATF rule against slotting allowances in the retail sale of alcohol beverages also would appear to apply to slotting practices that involve on-premise consumption outlets. 
rent public policy, further enhances our knowledge of slotting fees, and provides directions for additional research.

\section{Reconciling Public Policy}

In terms of public policy, our analysis reveals that unique political concerns and regulatory goals underlie the distribution and retail sale of alcohol beverages and provide contrary implications for the BATF's assessment of slotting allowance practices. In particular, political concerns about undesirable social outcomes, which have resulted in policy goals that attempt to control the widespread availability of alcohol beverages and discourage high levels of alcohol beverage consumption, are distinguishable from those found for other goods. In terms of slotting fees, these concerns and goals have translated into an objective of maintaining retailer independence and lead to the prohibition of practices, such as slotting fees, that are believed to jeopardize retailer independence and result in exclusionary outcomes.

The analysis also reveals that these concerns and regulatory goals have resulted in considerable federal and state restrictions for the overall industry and its distribution structure. Examination of the alcohol beverage industry shows that differences exist in the locus of influence and control in the industry compared with other retail sectors and that the available channels through which products can be introduced are more limited and regulated than for other products. Permitting slotting allowances in this context potentially could constrain further the available options for distribution, with the possibility of differentially disadvantaging small producers.

In addition, we identify as distinctive a variety of marketing practices with respect to alcohol products, including the nature of new products and their introduction, margins for alcohol versus other grocery products, and other factors. These practices further establish the unique nature of alcohol beverage marketing practices and distinguish them, relative to the practices that provide a basis and justification for slotting allowances in other contexts.

Finally, we identify the general nature of consumer consumption behavior toward alcohol beverage products as distinctive from that found for many grocery products, with a greater extent of consumption occurring on-premise. This distinction creates complications for the implementation of slotting allowance practices in the alcohol beverage industry.

Together, the variety of factors and distinctions identified for the retail sale of alcohol beverages provides some explanation and an argued basis for the BATF's differential treatment of slotting allowance practices. Understanding the basis of different public policy treatment toward a particular practice enables businesses to be more confident in their decision making, especially with regard to practices for which public policy is still developing or contrary agency perspectives are held.

\section{Understanding Slotting Fees}

In terms of our understanding of slotting fees, this analysis further enhances our knowledge of the occurrence, nature, practice, and effect of slotting allowance practices. In particular, it highlights the increasing occurrence of slotting fees in nongrocery products categories. Prior commentary has tended to focus mainly on this industry. The analysis provided here focuses on such practices outside the grocery products industry, in the context of alcohol beverages. Beyond grocery food products and alcohol beverages, slotting fees also have been reported by observers in the software (Radding 1989), music (Trachtenberg 1995), and pharmaceutical (Kiley 1989) industries and among booksellers (Tabor 1996). Further analysis of these contexts is required to understand fully the nature of this marketing practice.

In addition, the analysis reveals the expanding nature of slotting allowance practices. Of particular note in the extant case is that these fees appear to apply to existing, as well as new, products. As now defined by the BATF, slotting allowances include "the act by an industry member of purchasing or renting display, shelf, storage or warehouse space" (60 Federal Register 20424). This definition is not limited to new products but appears inclusive of existing products. An important implication of this perspective is that prior explanations of the efficiency-enhancing benefits of slotting allowance practices have emphasized their application with respect to new products. Expansion of such practices to include other than new products requires that these explanations be amended to include applications to existing products.

In relation, though the definition adopted by the BATF appears to include products, new or otherwise, it does emphasize "realty," with its identification of "display," "shelf," "storage," and "warehouse" space. This contrasts somewhat with the definitions of slotting allowances that emphasize all forms of retailer patronage and include such fees as are paid for making new product presentations, surveys, and failure (i.e., product removal) fees. At this time, it is not clear whether the BATF definition encompasses such practices. Although close examination of the regulations suggests that such practices might be included, in that this definition is provided as merely descriptive of such practices, just how nonrealty-based slotting allowance practices will be interpreted will have to wait application of the regulations by the BATF. Widespread comments initially prompted the BATF to expand its previous, even narrower proposed definition, which referred to "purchasing or renting specific shelf space," to include other realty space.

Our analysis also reveals additional information regarding the practice of slotting allowances. Although not characterized in the proposed regulations to be considered under the commercial bribery (see Table 2) part of the regulations, many commentators describe slotting fees as bribery or "payola" that is paid directly to an individual rather than the business entity itself. In addition, at least one commentator described such fees as providing the basis for exclusive outlets and called for the prohibition of such arrangements. In each case, these comments provide a glimpse of the practiced operationalizations of slotting allowance arrangements, as reported by industry participants. The nature of such practices suggest that these operationalizations might not be restricted exclusively to the alcohol beverage context. In this respect, each comment provides fertile territory for close public policy examination in other industries.

This analysis also provides information regarding the potential effects of slotting fees. These include effects beyond their characterization as jeopardizing retailer independence in the alcohol beverage industry and, as such, 
have potential implications for the evaluation of such practices in other contexts. In particular, small businesses, both manufacturers and retailers, were identified as being particularly disadvantaged by slotting allowance practices. Several commentators voiced their disapproval of the theory that these fees enable small manufacturers to introduce new products by "buying" their way into the market. Commentators suggested that such theory is unrealistic in application because usually small or start-up businesses do not have the funding to compete with larger companies for retailer space. In addition, it was observed that because these fees encompass, in some cases, bids for shelf space, they do not reflect the true costs they are supposed to capture. For small retailers, the disadvantages identified include the observation that individual stores and smaller chains have considerably less or no leverage in obtaining slotting fees. As a consequence, these smaller firms could be discriminated against in the receipt of these fees and receive a disproportionately lower allocation in the industry. These commentaries are revealing of the competitive implications of slotting allowances and should be useful for future public policy development.

\section{Additional Research}

Finally, with regard to scholarship, academic research of slotting allowance practices could take several directions. In terms of increasing our general understanding of slotting fees, further research is needed regarding the overall occurrence, nature, practice, and effects of these fees in other contexts. Although considerable attention has been given to this practice in the grocery context and in this study of alcohol beverages, as we mentioned, the practice of slotting allowances appears to be evolving in other product categories (e.g., pharmaceuticals, books, music products). Investigation of the nature of such strategies, as applied in each of these areas, is needed. Furthermore, research could be undertaken on how slotting fees have expanded to include both new and existing products. Research that captures more fully the context and practice of slotting is needed to understand this phenomenon fully.

In terms of public policy research, though our current research focuses on federal initiatives toward slotting fees and, in particular, treatment of these practices by the BATF, additional research might involve examining state-based policy. Activity at the state level has been reported on the part of the states' attorneys general offices and other agencies. For example, based on an increasing number of complaints, the California Attorney General's office initiated an investigation into slotting practices (Davey 1990; Kiley 1990a). Initiatives on the part of state officials represents, in part, their reaction to the lack of policy initiatives at the federal level and the number of received complaints. Examination of extant policy and current developments at the state level toward slotting practices is needed.

In addition to reviews of current public policy at the federal and state levels toward slotting allowances, further research also might involve examining more closely those arguments and rationales that underlie the different public policy positions that have developed. In particular, scholarly research that focuses on the theoretical logic attendant to these positions and their underlying assumptions could help reinforce current policy or future adaptations to these poli- cies. To date, the primary basis on which public policy has developed has been economic theorizing. Conceptual examination and empirical testing of the relationships that constitute these theories is needed to reconcile differing perspectives and increase the general understanding of these practices. In this respect, research that addresses the argued risk allocation and signaling basis of slotting fees provides one avenue for inquiry. Particular questions include the following: Do slotting fees play an efficient role in allocating the risk and costs of new products to those best positioned to control and absorb them? Do slotting fees actually serve as a credible signal with regard to the success or failure of a product? Do slotting fees serve to encourage manufacturers to research and support their products better?

In addition to these questions, investigation of the anticompetitive explanations of slotting allowances is required. These practices have been argued to be the result of exploited market power and have been objected to on the basis that they serve mainly as a mechanism for foreclosing less resourceful competition. Important research questions, in this respect, include those that focus on the transition of power in the marketing channel to the retail institutions and those that examine the competitive strategies of rival firms and their effects in the marketplace. For example, what structural and nonstructural factors have contributed to the increasing power of retail institutions? How do organizations view slotting allowance strategies in practice? What effects have slotting fees had on new product introductions, product line extensions, promotion dynamics, research and development, innovation, small firms in general, and large firms?

Finally, research on the effect slotting allowance practices have on consumers is required and includes a plethora of questions ranging from their impact on consumer prices and choice to the diffusion of innovation among consumers. Together, these and other research questions provide fertile territory for additional academic research.

\section{Conclusion}

The practice of slotting allowances, or fees, paid to retailers to obtain their patronage continues to receive attention from industry participants, public policymakers, and commentators. Considerable controversy and debate surrounds this competitive practice and its implications for participants and consumers. With this article, we attempt to contribute to this dialogue by examining current policy perspectives and recent rulemaking by the BATF that relate to slotting allowance practices in the alcohol beverage industry.

\section{References}

Aalberts, Robert J. and L. Lynn Judd (1991), "Slotting in the Retail Grocery Business: Does It Violate the Public Policy Goal of Protecting Businesses Against Price Discrimination?" Depaul Law Review, 40 (2), 397-416.

Adams/Jobson's Wine Handbook (1996a), "On-Premise Versus Off-Premise Retail Dollar Sales of Beverage Alcohol, 1987-1995." New York: Adams Media Group, 31. 
(1996b), "Share of Off-Premise Beverage Market Held by Grocery Stores, 1988-1994.” New York: Adams Media Group, 176.

Antitrust and Trade Regulation Report (1994), "FTC's Owen Examines Market Definition, Slotting Allowances at Grocers Seminar," Bureau of National Affairs, 66 (1669), 703.

Bellamy, Gail (1994), "Beer Blast: Innovations in Brewing," Restaurant Hospitality, 78 (2), 120.

Beloit Beverage Co. v. Winterbrook Corp. (1995), 900 F. Supp 1097.

Bronfman, Edgar M., Jr. (1993), "The Challenge for Brands: Building Brand Strength," Directors and Boards, 17 (4), 8.

Cannon, Joseph P. and Paul N. Bloom (1991), "Are Slotting Allowances Legal Under Antitrust Laws?" Journal of Public Policy \& Marketing, 10 (1), 167-86.

Charlier, Marj (1994), "Beer Makers Frothing over Plan to Charge for Retail Shelf Space," The Wall Street Journal, (April 22), B-1.

Dagnoli, Judann and Lori Freeman (1988), "Marketers Seek Slotting Fee Truce: New Promotions Would Help Retailers," Advertising Age, 59 (February 22), 12, 68.

Davey, Tom (1990), "State Probes Grocery 'Slotting Fee' Practices," The Business Journal-Sacramento, 7 (October 22), 1:1.

Donahue, Christine (1987), "Supermarket Shelf Space Up for Sale," Adweek's Marketing Week, 28 (August 24), 1.

(1989), "Getting Them Coming and Going," Adweek's Marketing Week, 30 (September 4), 20-24.

Dunkirk Ice Cream Co. v. Mid-Atlantic Ice Cream Co. (1996), 1996 U.S. District LEXIS 73:6.

E.J. Brock Corp. v. Filbert Int'l. Inc. (1991), 1991 U.S. District LEXIS S237.

Federal Alcohol Administration Act (1935), 27 USC 201 et. seq.

Federal Trade Commission Guides (1990), "Guides for Advertising Allowances and Other Merchandising Payments and Services," 16 CFR 240.9

Fedway Associates Inc. v. BATF (1992), 976 F.2d 1416.

Foremost Sales Promotions Inc. v. BATF (1988), 860 F.2d 229 (7th Cir.).

Freeman, Lori and Judann Dagnoli (1988), "FTC Centers Its Sights on Slotting Allowances," Advertising Age, 59 (July 4), 1. and Allison Fahey (1990), "Slotting Fees May Get FTC OK," Advertising Age, 61 (June 18), 4.

Friedman, Martin (1990), “98,900 New Products Later: The Major Packaged Goods Marketing Trends Noted in New Product News 1964-1989," New Product News, (April 8), 11.

Gibson, Richard (1988), "Supermarkets Demand Food Firms' Payments Just to Get on the Shelf," The Wall Street Journal, 83 (November 1), Al.

Gorman, John (1988), "Route to Grocers' Shelves Toll Road for Food Firms," Chicago Tribune, (January 24), 7:1.

Greenwald, John (1996), "Frito-Lay Under Snack Attack," Time, (June 10), 62-63.

Hammonds, Tim and Helmut Radtke (1990), "Price of Too Many Failures," Progressive Grocer, 69 (February), 46-47.

Hygrade Milk \& Cream Co. v. Tropicana Produce (1996), SS Civil 2861 (SAS), U.S. District LEXIS 659S.

Johnson, William C. (1988), "Sales Promotion Has Come Down to Push Marketing," Marketing News, 22 (February 29), 5.
Jones, Buck (1991) "Are Grocers Getting Too Greedy?" Progressive Grocer, 70 (10), 148.

Kelly, Kenneth (1991), "The Antitrust Analysis of Grocery Slotting Allowances, The Pro-Competitive Case," Journal of Public Policy \& Marketing, 10 (1), 187-98.

Kiley, David (1989), "Drug Chains Bleed Suppliers and Offer Little in Return," Adweek's Marketing Week, (September 4), 24-25.

(1990a), "California Probes Slotting Fee," Adweek's Marketing Week, 31 (October 8), 6.

(1990b), "No Relief in Sight on Slotting Fees," Adweek's Marketing Week, 31 (August 13), 9

Land O'Lakes Inc. v. Fredjo's Enterprises (1992), Case No. SS C 0716 , U.S. District, LEXIS 9224.

Lariviere, Martin A. and V. Padmanabhan (1997), "Slotting Allowances and New Product Introductions," Marketing Science, 16 (2), 112-28.

MacAvoy, Christopher J. (1997), "Antitrust Treatment of Slotting Allowances," presentation at ABA Section of Antitrust Law, 45th Annual Spring Meeting, Washington, DC (April 9-11).

McCabe, Harry (1996), "Slotting Allowances, Past and Future: A Panel Discussion," comments, 1996 Public Policy \& Marketing Conference, Arlington, VA (May 17).

National Distributing Company Inc. v. BATF (1980), 626 F.2d 997.

Partch, Ken, Mike Duff, and David Litwak (1990), "Trophies of the Trade War: Competition Among Supermarkets," Supermarket Business, 49 (5), 25.

Pennsylvania v. Russell Stover Candies Inc. (1993) 1993 U.S. Dist. LEXIS 6024: 1993-I Trade Case (CCN), pp. 70, 224.

Progressive Grocer (1990), "When Is an Allowance a Bribe?" 69 (May), 25.

(1991), "Buyer/Seller Relations: The Winds of War Still Blow," 70 (April), 34-37.

- (1996), "Finding a Slot," 75 (August), 14.

Radding, Alan (1989), "Egghead Loads up on Software Slotting," Advertising Age, (July 24), 70.

Radtke, Helmut (1990), "Slotting Allowances Hurt Everyone," Progressive Grocer, 69 (February), 46-47.

Rogers, Patrick and Sherry Keene-Osborn (1994), "Beer Lovers Going with the Flow," Newsweek, (May 23), 57.

Sales and Marketing Management (1989), "Slotting Allowances: Are They Here to Stay?" 141 (July), 77.

Scotts of Wisconsin v. R.P.S. Distributors (1993), No. CV 91310679; 1993. Conn. Super, LEXIS 1967.

Shaffer, Greg (1991), "Slotting Allowances and Retail Price Maintenance: A Comparison of Facilitating Practices," RAND Journal of Economics, 22 (1), 120-35.

Shapiro, Eben (1990), "New Products Clog Food Stores," New York Times, (May 28), D-1.

(1994), "Private-Label Beers Try to Brew Interest," The Wall Street Journal, (January 6), B5.

Smith, Kelly L. (1990), "An Equity Theory Approach to Examining the Effects of Unethical Practices in Marketing Channels," in Enhancing Knowledge Development in Marketing, William Bearden et al., eds. Chicago: American Marketing Association, 380.

Stern, Gabriella (1993), "Survival of the Fittest Is the Rule of the Shelf," The Wall Street Journal, (November 1), B-I. 
Stern, Louis W., Adel E. El-Ansary, and Anne T. Coughlan (1996), Marketing Channels. Upper Saddle River, NJ: Prentice Hall.

Sullivan, Lawrence Anthony (1977), Antitrust. St. Paul, MN: West Publishing.

Tabor, Mary B.W. (1996), "In Bookstores Chains, Display Space Is for Sale," New York Times, (January 15), A-1.
Tenser, James (1992), "On Tap: Marketing Beer to Local Tastes," Supermarket News, 42 (37), 26.

Therrien, Lois (1989), "Want Shelf Space at the Supermarket? Ante Up," BusinessWeek, (August 7), 60-61.

Trachtenberg, Jeffrey A. (1995), "Record Stores Lease Out Windows, Walls, Whatever," The Wall Street Journal, (April 19), B-1. 
Copyright of Journal of Public Policy \& Marketing is the property of American Marketing Association. The copyright in an individual article may be maintained by the author in certain cases. Content may not be copied or emailed to multiple sites or posted to a listserv without the copyright holder's express written permission. However, users may print, download, or email articles for individual use. 